\title{
Prolactin induces adrenal hypertrophy
}

\author{
E.J. Silva ${ }^{1}$, L.F. Felicio ${ }^{1}$, \\ A.G. Nasello ${ }^{2}$, \\ M. Zaidan-Dagli ${ }^{1}$ \\ and J.A. Anselmo-Franci ${ }^{3}$
}

\author{
1'Departamento de Patologia, Faculdade de Medicina Veterinária e Zootecnia, \\ Universidade de São Paulo, São Paulo, SP, Brasil \\ ${ }^{2}$ Departamento de Ciências Fisiológicas, \\ Faculdade de Ciências Médicas da Santa Casa, São Paulo, SP, Brasil \\ ${ }^{3}$ Departamento de Fisiologia, Faculdade de Odontologia de Ribeirão Preto, \\ Universidade de São Paulo, Ribeirão Preto, SP, Brasil
}

\author{
Correspondence \\ E.J. Silva \\ Departamento de Patologia \\ FMVZ, USP \\ Av. Prof. Orlando M. de Paiva, 87 \\ 05508-9000 São Paulo, SP \\ Brasil \\ E-mail: ejsilva@usp.bror \\ joao.e@ig.com.br \\ Research supported by CAPES, CNPq \\ and FAPESP.
}

Received November 29, 2002 Accepted September 25, 2003 $\ldots \ldots \ldots \ldots \ldots \ldots \ldots$

\begin{abstract}
Although adrenocorticotropic hormone is generally considered to play a major role in the regulation of adrenal glucocorticoid secretion, several reports have suggested that other pituitary hormones (e.g., prolactin) also play a significant role in the regulation of adrenal function. The aim of the present study was to measure the adrenocortical cell area and to determine the effects of the transition from the prepubertal to the postpubertal period on the hyperprolactinemic state induced by domperidone $\left(4.0 \mathrm{mg} \mathrm{kg}^{-1} \mathrm{day}^{-1}, s c\right)$. In hyperprolactinemic adult and young rats, the adrenals were heavier, as determined at necropsy, than in the respective controls: adults (30 days: $0.16 \pm 0.008$ and $0.11 \pm 0.007 ; 46$ days: $0.17 \pm 0.006$ and $0.12 \pm 0.008$, and 61 days: $0.17 \pm 0.008$ and $0.10 \pm 0.004 \mathrm{mg}$ for treated and control animals, respectively; $\mathrm{P}<0.05$ ), and young rats (30 days: $0.19 \pm 0.003$ and 0.16 \pm 0.007 , and 60 days: $0.16 \pm 0.006$ and $0.13 \pm 0.009 \mathrm{mg} ; \mathrm{P}<0.05)$. We selected randomly a circular area in which we counted the nuclei of adrenocortical cells. The area of zona fasciculata cells was increased in hyperprolactinemic adult and young rats compared to controls: adults: (61 days: $524.90 \pm 47.85$ and $244.84 \pm 9.03 \mu \mathrm{m}^{2}$ for treated and control animals, respectively; $\mathrm{P}<0.05)$, and young rats: (15 days: $462.30 \pm 16.24$ and $414.28 \pm 18.19 ; 60$ days: $640.51 \pm 12.91$ and $\left.480.24 \pm 22.79 \mu \mathrm{m}^{2} ; \mathrm{P}<0.05\right)$. Based on these data we conclude that the increase in adrenal weight observed in the hyperprolactinemic animals may be due to prolactin-induced adrenocortical cell hypertrophy.
\end{abstract} Key words - Pituitary - Domperidone - Dopamine

- Rats

- Morphometry

\section{Introduction}

Prolactin (PRL) is one of the most versatile hormones produced by the pituitary gland (1-3). Several properties of PRL are of particular interest with regard to the adrenal gland. It is known that glucocorticoids have a synergistic action with PRL on breast devel- opment. PRL is a stress-related peptide and hyperprolactinemia is frequently associated with hirsutism, hypogonadism, and amenorrhea in humans (4). It has been speculated that in these conditions PRL acts directly on the adrenal.

PRL stimulates steroidogenesis in the adrenal gland of rats and this effect seems to be 
synergistic with that of adrenocorticotropic hormone (ACTH) (5). PRL seems to be a 5 $\alpha$-reductase inhibitor and stimulates adrenal growth and corticosterone synthesis (6).

Several studies have reported that PRL has a stimulatory effect on human adrenal aldosterone-producing adenomas and on adrenocortical carcinoma $(7,8)$. Furthermore, PRL has been shown to be involved in the cell proliferation of normal and neoplastic tissues and to activate the mitogen-activated protein kinase cascade in primary cultures of leiomyoma cells, breast cancer cells and $\mathrm{Nb}$ 2 cell lines (8).

Other investigators have reported that hyperprolactinemic rats and mice show an increase in absolute and relative adrenal weight $(6,9,10)$. However, these reports did not refer to any histological changes in the adrenal glands. Furthermore, most of these studies were conducted on adult animals. In the present study we investigated the effects of hyperprolactinemia on the adrenal glands of pre- (42-47 days) and postpubertal (75-90 days) rats. Our aim was to measure the area of adrenocortical cells and to investigate the effects of the transition from the prepubertal to the postpubertal period on the hyperprolactinemic state induced by domperidone (11-14).

\section{Material and Methods}

\section{Animal treatment}

Young (42-47 days) and adult (70-90 days) Wistar rats were used. The animals were maintained under standard conditions of light (12 h light/12 h dark) and temperature $\left(23 \pm 1^{\circ} \mathrm{C}\right)$, with free access to laboratory food and water.

All animals in the experimental groups received a daily subcutaneous injection of domperidone ( $4.0 \mathrm{mg} / \mathrm{kg}$ body weight) dissolved in saline plus Tween 80 . The animals of the control groups received saline plus Tween 80 . The period of treatment was 15 ,
$30,45 / 48$, or $60 / 61$ days. Twenty-four hours after the last administration of domperidone or saline, the rats were decapitated and trunk blood was collected. Blood was collected between 10:00 am and 3:00 pm, a period during which the daily rhythm of prolactin secretion remains relatively stable (15).

Body weight and the weight of the two adrenals were determined at autopsy. Only the left adrenal was used for the morphometric and histological studies.

\section{Light microscopy}

The adrenal glands were removed, freed of adhering fat and weighed. The left adrenals were fixed in Bouin's solution, embedded in paraffin and serially cut into $5-7-\mu \mathrm{m}$ sections. The sections were then stained with hematoxylin and eosin.

\section{Morphometry}

A single paraffin section containing the zona medullaris was chosen for adrenal gland morphometry. In this section 50 test areas of the outer zona fasciculata (ZF) were counted (16). Since the adrenocortical cells of rats are mononucleated, the numerical density of the nuclei corresponds to the number of cell per $\mathrm{mm}^{3}(16,17)$.

The test area was measured with a $10 \mathrm{X}$ objective using the Image-Pro Plus software. To measure these areas we chose a circular area with the aid of this software, in which we counted the nuclei. After this procedure, we were able to calculate the area of the ZF adrenocortical cells of the adrenal gland by dividing the number of nuclei counted by the circular area measured $(16,17)$. These measurements were performed only in the groups treated for 15 and 60 days.

\section{Hormone assays}

PRL concentration was determined by double antibody radioimmunoassay using 
specific kits provided by the National Institute of Diabetes and Digestive and Kidney Diseases (NIDDK, Baltimore, MD, USA). The antiserum for PRL was anti-rat PRL-S9 and the reference preparations were PRLRP3. The lower limit of PRL detection was $0.19 \mathrm{ng} / \mathrm{ml}$. The intra-assay and interassay coefficients of variation were 4 and $11.5 \%$ for PRL, respectively. Prolactin levels are reported as $\mathrm{ng} / \mathrm{ml}$.

\section{Statistical analysis}

The data obtained for each rat were averaged per group and the standard error of the mean was calculated. The Mann-Whitney test was used for statistical comparison of mean adrenal weight and PRL levels between the treated and control groups. A value of $\mathrm{P} \leq 0.05$ was considered to be statistically significant.

\section{Results}

Table 1 shows the absolute and relative weights of the adrenal glands from adult rats. Treatment with domperidone for 30 or more days resulted in an increase in the weight of the adrenal glands and their relative weight in adult rats.

Table 2 shows the results obtained for young animals. As observed in the adult rats, there was an increase in the adrenal weights after long-term treatment, with the exception of animals treated for 48 days. The increase in adrenal weight was more pronounced in adult animals treated with domperidone than in young animals compared to the respective control.

Table 3 shows the data obtained by morphometric analysis concerning the adrenocortical cell area, in $\mu \mathrm{m}^{2}$, for the adult and young animals. There was an increase in $\mathrm{ZF}$ cell area in young and adult rats treated with domperidone for 15 and 60/61 days, but not in adult rats treated for 15 days.

Serum PRL levels were significantly in- creased throughout treatment in all experimental groups, except for young animals treated for 15 and 48 days (Table 4 ).

Figure 1 shows histological sections of adrenal glands stained with hematoxylin and eosin. The treated animals (Figure 1B) had fewer "clear cells" (vacuolated adrenocortical cells) than control animals (Figure 1A).

Table 1. Effect of hyperprolactinemia induced by domperidone on adrenal weights of adult rats.

\begin{tabular}{lcccc}
\hline Groups & $\begin{array}{c}\text { Duration of } \\
\text { treatment } \\
\text { (days) }\end{array}$ & $\begin{array}{c}\text { Body weight } \\
(\mathrm{g})\end{array}$ & $\begin{array}{c}\text { Adrenal } \\
\text { weights } \\
\text { (mg/pair) }\end{array}$ & $\begin{array}{c}\text { Relative } \\
\text { adrenal } \\
\text { weight }\end{array}$ \\
\hline Experimental $(\mathrm{N}=7)$ & 15 & 380.57 & $68.30 \pm 4.20$ & $0.18 \pm 0.012$ \\
Control $(\mathrm{N}=6)$ & & 361.67 & $65.30 \pm 7.81$ & $0.18 \pm 0.017$ \\
Experimental ( $\mathrm{N}=7)$ & 30 & 373.57 & $59.57 \pm 2.36^{*}$ & $0.16 \pm 0.008^{*}$ \\
Control $(\mathrm{N}=7)$ & & 419.71 & $48.00 \pm 3.46$ & $0.11 \pm 0.007$ \\
Experimental $(\mathrm{N}=7)$ & 46 & 344.23 & $58.71 \pm 3.01^{*}$ & $0.17 \pm 0.006^{*}$ \\
Control $(\mathrm{N}=6)$ & & 356.27 & $42.33 \pm 2.87$ & $0.12 \pm 0.008$ \\
Experimental $(\mathrm{N}=8)$ & 61 & 384.50 & $64.88 \pm 2.30^{*}$ & $0.17 \pm 0.008^{*}$ \\
Control $(\mathrm{N}=7)$ & & 404.00 & $42.00 \pm 2.45$ & $0.10 \pm 0.004$ \\
\hline
\end{tabular}

The rats (aged 70-90 days at the beginning of treatment) received $4.0 \mathrm{mg} / \mathrm{kg}$ domperidone, sc. Relative adrenal weight $=$ adrenal weights/body weight. Data are reported as means \pm SEM for $\mathrm{N}$ rats in each group. $\mathrm{P}<0.05$ compared to respective control (Mann-Whitney test).

Table 2. Effect of hyperprolactinemia induced by domperidone on adrenal weights of young rats.

\begin{tabular}{lcccc}
\hline Groups & $\begin{array}{c}\text { Duration of } \\
\text { treatment } \\
\text { (days) }\end{array}$ & $\begin{array}{c}\text { Body weight } \\
(\mathrm{g})\end{array}$ & $\begin{array}{c}\text { Adrenal } \\
\text { weights } \\
\text { (mg/pair) }\end{array}$ & $\begin{array}{c}\text { Relative } \\
\text { adrenal } \\
\text { weight }\end{array}$ \\
\hline Experimental $(\mathrm{N}=10)$ & 15 & 238.00 & $47.30 \pm 2.43$ & $0.20 \pm 0.013$ \\
Control $(\mathrm{N}=10)$ & & 229.80 & $46.30 \pm 1.67$ & $0.20 \pm 0.009$ \\
Experimental $(\mathrm{N}=8)$ & 30 & 315.95 & $58.13 \pm 1.01^{*}$ & $0.19 \pm 0.003^{*}$ \\
Control ( $=8)$ & & 315.53 & $51.13 \pm 2.07$ & $0.16 \pm 0.007$ \\
Experimental $(\mathrm{N}=8)$ & 48 & 349.25 & $51.00 \pm 3.80$ & $0.15 \pm 0.010$ \\
Control ( $=8)$ & & 359.38 & $46.63 \pm 3.62$ & $0.13 \pm 0.010$ \\
Experimental $(\mathrm{N}=8)$ & 60 & 376.75 & $59.13 \pm 2.25^{*}$ & $0.16 \pm 0.006^{*}$ \\
Control $(\mathrm{N}=7)$ & & 362.57 & $48.14 \pm 2.81$ & $0.13 \pm 0.009$
\end{tabular}

The rats (aged 42-47 days at the beginning of treatment) received $4.0 \mathrm{mg} / \mathrm{kg}$ domperidone, sc. Relative adrenal weight $=$ adrenal weights/body weight. Data are reported as means \pm SEM for $N$ rats in each group. $P<0.05$ compared to respective control (Mann-Whitney test). 


\section{Discussion}

Adrenal cells of the zona glomerulosa have little cytoplasm containing only a small amount of lipid. The ZF is the broadest of all the three zones of the adrenal, which makes up about $75 \%$ of the total cortex. Its cells are polyhedral and have many intracytoplasmic lipid droplets (18). These lipids, mostly cholesterol and cholesterol esters, are used as substrates for steroidogenesis (19). These lipid droplets can be mobilized from these stores to mitochondria for the synthesis of

\begin{tabular}{|c|c|c|}
\hline \multirow[b]{2}{*}{ Adult rats } & \multicolumn{2}{|c|}{ Duration } \\
\hline & 15 days & 61 days \\
\hline Experimental & $496.92 \pm 10.60$ & $524.90 \pm 47.85^{*}$ \\
\hline Control & $459.43 \pm 19.65$ & $244.84 \pm 9.03$ \\
\hline Young rats & 15 days & 60 days \\
\hline Experimental & $462.30 \pm 16.24^{*}$ & $640.51 \pm 12.91 *$ \\
\hline Control & $414.28 \pm 18.19$ & $480.24 \pm 22.79$ \\
\hline
\end{tabular}

Rats received $4 \mathrm{mg} / \mathrm{kg}$ domperidone, sc. Data are reported as means $\pm \mathrm{SEM}$ in $\mu \mathrm{m}^{2}$ for 4 rats in each group.

${ }^{*} \mathrm{P}<0.05$ compared to respective control (MannWhitney test).

Table 4. Serum prolactin levels of adult and young animals treated with domperidone.

\begin{tabular}{ccccc}
\hline \multicolumn{5}{c}{ Duration } \\
\hline Adult rats & 15 days & 30 days & 46 days & 61 days \\
Experimental & $193.17 \pm 19.37^{*}$ & $303.87 \pm 31.43^{*}$ & $251.95 \pm 35.76^{*}$ & $246.95 \pm 34.81^{*}$ \\
& $\mathrm{~N}=7$ & $\mathrm{~N}=8$ & $\mathrm{~N}=7$ & $\mathrm{~N}=7$ \\
Control & $25.75 \pm 8.12$ & $18.28 \pm 2.84$ & $7.40 \pm 1.21$ & $19.44 \pm 2.37$ \\
& $\mathrm{~N}=6$ & $\mathrm{~N}=6$ & $\mathrm{~N}=6$ & $\mathrm{~N}=7$ \\
Young rats & 15 days & 30 days & 48 days & 60 days \\
Experimental & $19.70 \pm 1.87$ & $20.09 \pm 3.44^{*}$ & $72.16 \pm 19.94$ & $217.87 \pm 42.11^{*}$ \\
& $\mathrm{~N}=10$ & $\mathrm{~N}=8$ & $\mathrm{~N}=9$ & $\mathrm{~N}=8$ \\
Control & $13.70 \pm 5.53$ & $2.76 \pm 0.31$ & $47.30 \pm 17.08$ & $24.47 \pm 5.99$ \\
& $\mathrm{~N}=10$ & $\mathrm{~N}=7$ & $\mathrm{~N}=7$ & $\mathrm{~N}=7$ \\
\hline
\end{tabular}

Rats received $4 \mathrm{mg} / \mathrm{kg}$ domperidone, $s c$. Data are reported as means $\pm \mathrm{SEM}$ in $\mathrm{ng} / \mathrm{ml}$ for $\mathrm{N}$ rats in each group.

${ }^{*} \mathrm{P}<0.05$ compared to respective control (Mann-Whitney test). steroids. ZF cells are larger and contain more lipid than zona glomerulosa cells (20), and appear to be somewhat paler ("clear cells") in routinely stained tissue because of the microvacuolation of the cytoplasm. When stimulated to produce steroids, the clear cells are transformed into compact cells as the stored cholesterol is depleted. The zona reticularis is composed of aggregates of deeply acidophilic nonvacuolated cells ("compact" or "dark cells") devoid of apparent lipid (21). Depletion of lipid droplets in adrenal ZF cells has been reported to occur after stimulation with ACTH by a process that was termed endoplasmocrine secretion (22). Bornstein et al. (23) also demonstrated that lipid droplets were reduced in hypophysectomized rats treated with corticotropinreleasing hormone. At the electron microscope level these investigators observed that ZF cells presented features characteristic for stimulated glands. It is known that $\mathrm{ACTH}$ stimulation of the adrenocortical cells and corticotropin-releasing hormone treatment result in depletion of lipid droplets (23).

The reduction of the number of "clear cells" observed in the present study is consistent with that observed in guinea pigs treated with ACTH which decreased the number of lipid droplets in ZF cells (18). The decrease in the number of lipid droplets in $\mathrm{ZF}$ cells resulted in the reduction of the foamy appearance that is normal for the "clear cells". Depletion of lipid droplets in ZF cells also occurs in animals exposed to stress (24).

There is a direct relationship between adrenal gland activity and increased gland weight (20). Hypertrophy and macroscopic hyperemia have been described in response to administration of $\mathrm{ACTH}$, or following prolonged exposure to stress (20).

Some reports have suggested that PRL has an adrenoglomerulotrophic action (17). The increase in adrenal weight observed here may be due to the elevated levels of PRL.

We did not find mitotic figures in any 
group and proliferating cell nuclear antigen analysis showed no difference between the groups studied. Based on these data and on morphometric analysis, we conclude that the increase in adrenal weight is a consequence of adrenocortical cell hypertrophy. The present data are consistent with those reported by Glasow et al. (25) using human adrenal cells in primary culture. The results suggest that PRL is not mitogenic to adrenocortical cells. Apparently young animals are more responsive to PRL-induced hypertrophy of the adrenocortical cells than adult animals. Since the estimate of the adrenocortical cell area is indirect, it is not possible to correlate the increase in adrenal weight observed in treated animals with the increase in adrenocortical cell area. Nevertheless, it is clear that the increase in the adrenal weight of treated animals was more robust in adult rats compared to their respective control.

The reduction in the number of "clear cells" may have been due to stimulation of the adrenals by elevated PRL levels in treated animals.

There were no differences in serum PRL levels between young animals treated with domperidone for 15 days or for 30 days. This shows that domperidone is not able to induce a major increase in serum PRL levels in young rats as it does in adult male rats. Since it is known that stress can rapidly increase serum PRL levels $(26,27)$, perhaps the stress in these young animals is not effective in additionally increasing the levels of PRL. In prepubertal rats, the hyperprolactinemic response to domperidone was only evident in the animals treated for 30 and 60 days. Domperidone-induced hyperprolactinemia was even more evident in adult animals treated for 60 days. This suggests a role of sexual steroid hormones in the mechanism of hyperprolactinemia and, eventually, in the adrenal response to these stimuli. On the other hand, the response of postpubertal rats to short- and long-term treatment was about the same. These data suggest that young are less responsive to hyperprolactinemia than adult animals treated for the same period of time (i.e., 15 and 30 days).

It is known that in male rats testosterone reduces the adrenal weight and the volume of the adrenocortical cell nuclei (27). Furthermore, the increase in testosterone causes a reduction in serum ACTH levels (16), while testosterone injections in intact male rats inhibit ACTH secretion (28). Long-term
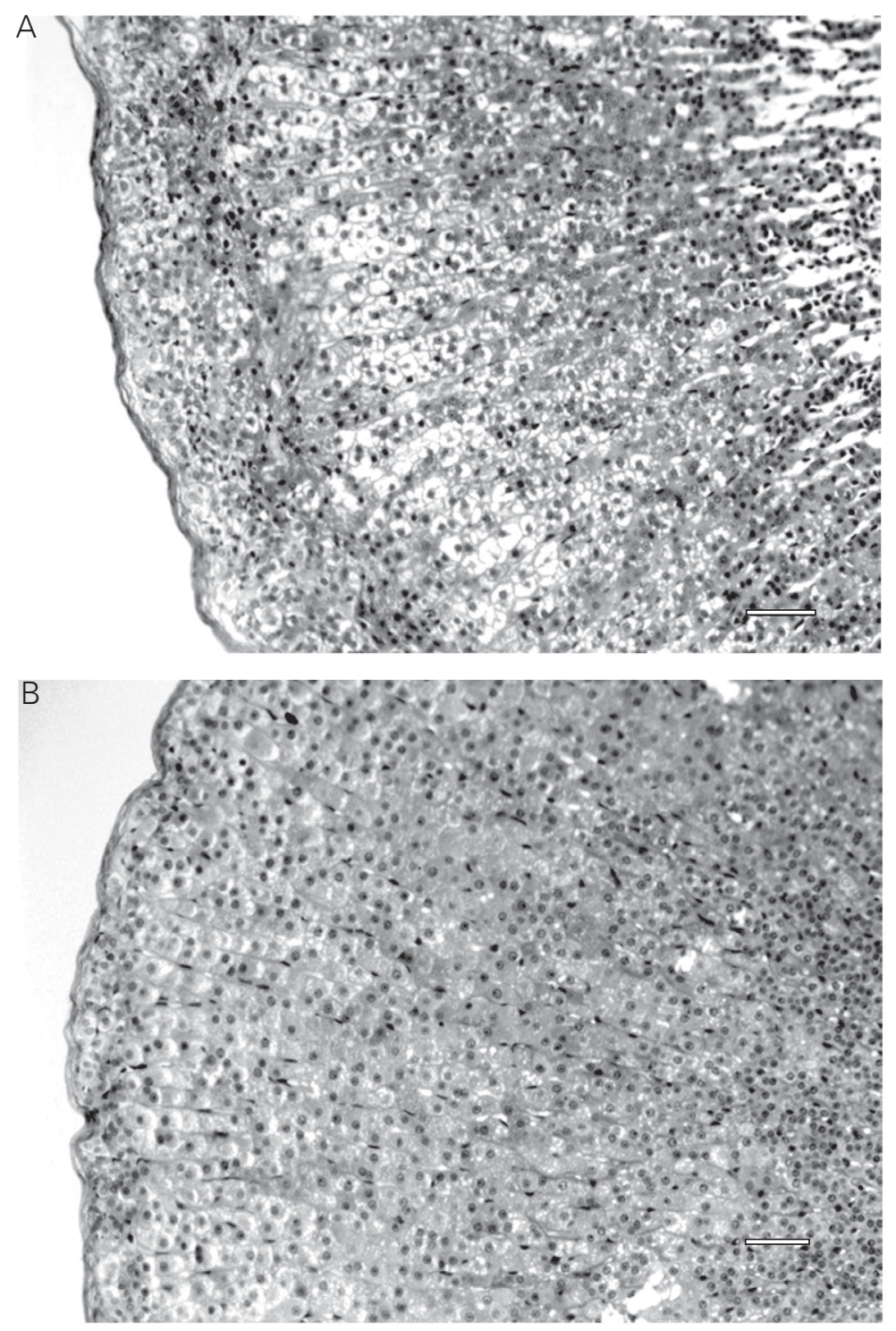

Figure 1 - Effect of domperidone administration on the zona fasciculata of rat adrenal glands. The rats were treated with $4.0 \mathrm{mg} / \mathrm{kg}$ domperidone $s c$ for 60 days. The large number of vacuoles in the untreated control (A) was reduced by domperidone treatment (B). Bar $=10.28 \mu \mathrm{m}$. 
hyperprolactinemia (i.e., 30 days) results in a decrease in serum testosterone levels in adult male rats $(29,30)$. PRL stimulates the activity of $5 \alpha$-reductase leading to a decrease in testosterone production. Thus, it is reasonable to assume that the effect of hyperprolactinemia was more important than the inhibitory action of testosterone and the increase observed in the adrenals of treated rats is consistent with the role of high PRL levels. Therefore, the domperidone-induced adrenal hypertrophy was probably due to a gonadal steroid-dependent drug-induced hyperprolactinemia.

\section{References}

1. Ben-Jonathan N, Arbogast LA \& Hyde JF (1989). Neuroendocrine regulation of prolactin release. Progress in Neurobiology, 33: 399447.

2. Nasello AG \& Felicio LF (1991). Prolactin molecular interactions and behavioral effects. Ciência e Cultura, 43: 432-438.

3. Neil JD \& Nagy GM (1994). Prolactin secretion and its control. In: Knobil E \& Neill J (Editors), The Physiology of Reproduction. Vol. 1. 2nd edn. Raven Press, New York, 1833-1860.

4. Glasow A, Breidert M, Haidan A, Anderegg U, Kelly PA \& Bornstein SR (1996). Functional aspects of the effect of prolactin (PRL) on adrenal steroidogenesis and distribution of the PRL receptor in the human gland. Journal of Clinical Endocrinology and Metabolism, 81: 3103-3111.

5. Ogle TF \& Kitay JI (1979). Interactions of prolactin and adrenocorticotropin in the regulation of adrenocortical secretions in female rats. Endocrinology, 104: 40-44.

6. Fang VS, Refetoff S \& Rosenfield RL (1974). Hypogonadism induced by a transplantable prolactin producing tumor in male rats: hormonal and morphological studies. Endocrinology, 95: 991-998.

7. Carroll JE, Campanile CP \& Goodfriend TL (1982). The effect of prolactin on human aldosterone-producing adenomas in vitro. Journal of Clinical Endocrinology and Metabolism, 54: 689-692.

8. Bole-Feysot C, Goffin V, Edery M, Binart N \& Kelly PA (1998). Prolactin (PRL) and its receptor: actions, signal transduction pathways and phenotypes observed in PRL receptor knockout mice. Endocrine Reviews, 19: 225-268.

9. Bartke A, Smith MS, Michael SD, Peron FG \& Dalterio S (1977). Effect of experimentally-induced chronic hyperprolactinemia on testosterone and gonadotropin levels in male rats and mice. Endocrinology, 100: 182-186.

10. Bartke A, Doherty PC, Steger RW, Morgan WW, Amador AG, Herber DC, Siler-Khodr TM, Smith MG, Klemcke HG \& Hymer WC (1984). Effects of estrogen-induced hyperprolactinemia on endocrine and sexual functions in adult male rats. Neuroendocrinology, 39: 126135.

11. Vanzeler MLA, Felicio LF \& Nasello AG (1990). Chronic domperidone treatment effects on rat conditioned avoidance behavior. Brazilian Journal of Medical and Biological Research, 23: 865-868.

12. Nasello AG, Vanzeler MLA \& Felicio LF (1991). A comparison of bromopride and domperidone effects on rat conditioned avoidance and motor activity. Pharmacology and Toxicology, 68: 46-50.

13. Felicio LF \& Bridges RS (1992). Domperidone induces a probenecidsensitive rise in immunoreactive prolactin in cerebroventricular perfusates in female rats. Brain Research, 573: 133-138.

14. Nasello AG, Gidali D, De Sá-Rocha LC \& Felicio LF (1995). Differential effects of bromopride and domperidone on cholinesterase activity in rat tissues. Life Sciences, 56: 151-156.
15. Oliveira MC, Moraes JT, Barros HMT \& Barbosa-Coutinho LM (1996). Effects of estrogen and neuroleptics on prolactin secretion and immunoreactive prolactin cells. Brazilian Journal of Medical and Biological Research, 29: 521-525.

16. Malendowicz LK, Robba C \& Nussdorfer GG (1986). Sex differences in adrenocortical structure and function. XXII. Light- and electronmicroscopic morphometric studies on the effects of gonadectomy and gonadal hormone replacement on the rat adrenal cortex. Cell and Tissue Research, 244: 141-145.

17. Majchrzak M \& Malendowicz LK (1983). Sex differences in adrenocortical structure and function. XII. Sterologic studies of rat adrenal cortex in the course of maturation. Cell and Tissue Research, 232: 457-469.

18. Yuan BB, Tchao R, Funae $Y$, Voigt JM \& Colby HD (1998). Effects of ACTH administration on zonation of the guinea pig adrenal cortex. Molecular and Cellular Endocrinology, 146: 129-136.

19. Rosol TJ, Yarrington JT, Latendresse J \& Capen CC (2001). Adrenal gland: structure, function, and mechanisms of toxicity. Toxicologic Pathology, 29: 41-48.

20. Bassett JR \& West SH (1997). Vascularization of the adrenal cortex: its possible involvement in the regulation of steroid hormone release. Microscopy Research and Technique, 36: 546-557.

21. Cotran RS, Kumar V \& Robbins SL (1994). Robbin's Pathologic Basis of Disease. 5th edn. WB Saunders Company, Philadelphia, PA, USA.

22. Pudney J, Sweet PR, Vinson GP \& Whitehouse BJ (1981). Morphological correlates of hormone secretion in the rat adrenal cortex and the role of filopodia. Anatomical Record, 201: 537-551.

23. Bornstein SR, Ehrhart M, Scherbaum WA \& Pfeiffer EF (1990). Adrenocortical atrophy of hypophysectomized rats can be reduced by corticotropin-releasing hormone (CRH). Cell and Tissue Research, 260: 161-166.

24. Sharawy M, Dirksen T \& Chaffin J (1979). Increase in free cholesterol content of the adrenal cortex after stress: radioautographic and biochemical study. American Journal of Anatomy, 156: 567576.

25. Glasow A, Haidan A, Gillepsie J, Kelly PA, Chrousos GP \& Bornstein SR (1998). Differential expression of prolactin receptor (PRLR) in normal and tumorous adrenal tissues: separation of cellular endocrine compartments by laser capture microdissection (LCM). Endocrine Research, 24: 857-862.

26. Felicio, LF, Miranda WL \& Nasello AG (1988). Prolactin levels in male and female rats perinatally treated with bromopride. Brazilian Journal of Medical and Biological Research, 21: 133-136.

27. Malendowicz LK (1974). Sex differences in adrenocortical structure and function. I. The effects of post-pubertal gonadectomy and gonadal hormone replacement on nuclear volume of adrenocortical 
cells in the rat. Cell and Tissue Research, 151: 525-528.

28. Kitay JI, Coyne MD, Nelson R \& Newson V (1966). Relation of the testis to the adrenal enzyme activity and adrenal corticosterone production in the rat. Endocrinology, 78: 1061-1066.

29. Nasello AG, Felicio LF \& Cisternas JR (1995). Interrelación dopamina-prolactina-comportamiento. Revista Argentina de Endocrinología y Metabolismo, 32: 117-124.

30. Nasello AG, Vanzeler MLA, Madureira EH \& Felicio LF (1997). Effects of acute and long-term domperidone treatment on prolactin and gonadal hormone levels and sexual behavior of male and female rats. Pharmacology, Biochemistry and Behavior, 58: 10891094. 